\title{
Heterocycles for Alzheimer Disease: 4- and 5-Substituted Benzothiophenes as Starting Scaffold in the Construction of Potential New Inhibitors of BACE 1
}

Maria Funicello*, Iole Cerminara and Lucia Chiummiento

Department of Science, University of Basilicata, Via dell'Ateneo Lucano 10, 85100 Potenza, Italy

\begin{abstract}
4- and 5-substituted benzothiophenes were synthesized as starting scaffold in the construction of benzothieno[ $b]$ pyridines. Such structures were designed as potential new inhibitors of BACE 1. Preliminary promising biological data were reported. These molecules represent a starting point for improved chemicals in Alzheimer's disease treatment. Obtained preliminary results encourage research advance and further developments.
\end{abstract}

Keywords: Heterocycles; Benzothiophene; Scaffold; Small molecules; Benzothienopyridine; Beta-secretase; Alzheimer's disease

\section{Introduction}

Heterocycles are among the earliest organic compounds to be purified and recognized as discrete substances, although their structures remained unknown for a long time. The science of chemistry had a rapid progress since the first half of the nineteenth century [1] and the interest in heterocycles has increased over the years and continues to captivate many chemists worldwide. In particular, medicinal chemistry is intimately associated with heterocyclic compounds: in fact most of all known drugs contain heterocyclic frameworks [2].

There is therefore an increasing need and a specific request for new heterocyclic systems, both to find new structures and to optimize lead compounds [3-5]. Among heterocyclic compounds, benzothiophene shows a wide spectrum of biological activities [6] and its derivatives find use in pharmaceuticals, pesticides and in general organic synthesis $[7,8]$. The benzo $[b]$ thiophene ring system has long been recognized as an excellent scaffold for the development of bioactive compounds [913], in particular as isostere for naturally indoles and/or used in its own right to develop novel pharmacophores. Its derivatives are currently used in pharmaceutical as estrogen receptor antagonists [14-16], antimitotic agents [17-19], modulators of multidrug resistance [20], angiogenesis inhibitors [21-23], cognition enhancers [24], antifungal $[25]$ and anti-inflammatory $[26,27]$ agents. Indeed, benzo $[b]$ thiophenes may be regarded as a "privileged class" of structure from which druglike bioactives can be reasonably readily developed.

In our long research on heterocyclic synthesis and application [28], we focused, in particular, on substituted benzothiophenes, namely 4and 5- derivatives, and here we will discuss their preparation and their use as starting scaffold for the synthesis of more complex heterocyclic structure such as functionalized benzothienopyridines.

Alzheimer Disease is a neurological pathology that in the last ten years is increasingly widespread and still can not cure. Moreover it's well known that BACE1 plays a key role in the development of Alzheimer's disease and its inhibition is a therapeutic target [29-31]. Hence we will report the synthesis and activity of benzothieno[b]pyridines, small tricyclic molecules just known for many other biological activities.

\section{Experimental}

\section{General}

Column chromatography was carried out on Merck silica gel (0.063-0.200 $\mathrm{mm}$ particle size) by progressive elution with petroleum ether/ethyl acetate or petroleum ether/diethyl ether mixtures. ${ }^{1} \mathrm{H}$ - and ${ }^{13} \mathrm{C}$-NMR spectra were normally recorded for $\mathrm{CDCl}_{3}$ solutions on a Bruker AM $300 \mathrm{MHz}$ or on Varian INOVA 400 and $500 \mathrm{MHz}$ instruments. IR spectra were registered on a JASCO FT/IR 460 Plus. Mass spectra were obtained with a Hewlett-Packard 5971 mass-selective detector on a Hewlett-Packard GC/MS 6890-5973 system. Dichloromethane was dried with anhydrous $\mathrm{CaCl}_{2}$; THF was dried using sodium/benzophenone. Dry dimethylformamide was commercially available.

5-aminobenzo[ $b]$ thiophene (Maybridge), 4-oxo-4,5,6,7tetrahydrobenzo[b]thiophene (Sigma Aldrich) and 2-pyrrolidinone hydrotribromide were commercially available. All the described compounds were synthesized and characterized in previous work [32], except the following

\section{5-Br-4-oxo-4,5,6,7-tetrahydrobenzo[b] thiophene (2)}

In a two-neck flask, 4-oxo-4,5,6,7-tetrahydrobenzo[b]thiophene (1) (504 mg, $3.31 \mathrm{mmol}$ ) was dissolved in $40 \mathrm{~mL}$ of anhydrous $\mathrm{CH}_{2} \mathrm{Cl}_{2}$. Under argon atmosphere, 2-pyrrolidinone hydrotribromide $(1.80 \mathrm{~g}$, $3.64 \mathrm{mmol}$ ) was slowly added and the mixture was stirred at room temperature for 19 hours. Then the mixture was heated $\left(50^{\circ} \mathrm{C}\right)$ for 2 hours. The quench is performed by addition of saturated solution of $\mathrm{Na}_{2} \mathrm{~S}_{2} \mathrm{O}_{3}$, extraction and washing with $\mathrm{HCl} 10 \%$. The organic phase was dried over $\mathrm{Na}_{2} \mathrm{SO}_{4}$ and then concentrated under reduced pressure. The product (2) was obtained as yellow solid.

Melting point: $79-81^{\circ} \mathrm{C}$.

MS: m/z $231\left(\mathrm{M}^{+}\right) ; 121(100)$

${ }^{1} \mathrm{H}-\mathrm{NMR}\left(500 \mathrm{MHz}, \mathrm{CDCl}_{3}\right): \delta_{\mathrm{H}}=7.47-7.45(\mathrm{~d} ; 1 \mathrm{H}) ; 7.15-7.13$ $(\mathrm{d} ; 1 \mathrm{H}) ; 4.65-4.60(\mathrm{t} ; 1 \mathrm{H}) ; 3.37-3.20(\mathrm{~m} ; 2 \mathrm{H}) ; 3.123 .02(\mathrm{~m} ; 2 \mathrm{H})$

${ }^{13} \mathrm{C}-\mathrm{NMR}\left(125 \mathrm{MHz}, \mathrm{CDCl}_{3}\right): \delta_{\mathrm{C}}=185.00 ; 154.57 ; 137.59 ; 125.51$; $124.23 ; 49.57 ; 33.00 ; 22.26$

*Corresponding author: Maria Funicello, Department of Science, University of Basilicata, Via dell'Ateneo Lucano 10, 85100 Potenza, Italy, Tel: +300971205490/+393204371612; E-mail: maria.funicello@unibas.it

Received May 24, 2016; Accepted May 28, 2016; Published June 02, 2016

Citation: Funicello M, Cerminara I, Chiummiento L (2016) Heterocycles for Alzheimer Disease: 4- and 5-Substituted Benzothiophenes as Starting Scaffold in the Construction of Potential New Inhibitors of BACE 1. Med chem (Los Angeles) 6: 377-384. doi:10.4172/2161-0444.1000373

Copyright: (c) 2016 Funicello M, et al. This is an open-access article distributed under the terms of the Creative Commons Attribution License, which permits unrestricted use, distribution, and reproduction in any medium, provided the original author and source are credited. 


\section{5-Bomine-4-Hydroxybenzothiophene (3)}

${ }^{1} \mathrm{H}-\mathrm{NMR}\left(500 \mathrm{MHz}, \mathrm{CDCl}_{3}\right): \delta_{\mathrm{H}}=7.39-7.29(\mathrm{~d} ; 1 \mathrm{H}) ; 7.28-7.27$ $(\mathrm{d} ; 1 \mathrm{H}) ; 7.26-7.16(\mathrm{~d} ; 1 \mathrm{H}) ; 7.23-7.22(\mathrm{~d} ; 1 \mathrm{H}) ; 5.75(\mathrm{~s} ; 1 \mathrm{H})$

${ }^{13} \mathrm{C}-\mathrm{NMR}\left(125 \mathrm{MHz}, \mathrm{CDCl}_{3}\right): \delta \mathrm{C}=147.50 ; 141.92 ; 127.37 ; 126.36$; $120.59 ; 115.73 ; 103.83 ; 78.59$.

\section{MS: $\mathrm{m} / \mathrm{z} 230\left(\mathrm{M}^{+}\right)$}

Compounds 40 and 41 were obtained as byproduct in the Staudinger reaction: they are known compounds and here we report only NMR and MS charactherization.

\section{Compound 40}

${ }^{1} \mathrm{H}-\mathrm{NMR}\left(400 \mathrm{MHz}, \mathrm{CDCl}_{3}\right): \delta_{\mathrm{H}}=7.41(\mathrm{~m} ; 1 \mathrm{H}) ; 7.13-7.11(\mathrm{~d} ; 1 \mathrm{H})$; $6.98(\mathrm{~m} ; 1 \mathrm{H}) ; 6.63-6.61(\mathrm{~d} ; 1 \mathrm{H}) ; 6.38(\mathrm{~s} ; 1 \mathrm{H}) ; 3.83(\mathrm{~s} ; 3 \mathrm{H})$

MS: $\mathrm{m} / \mathrm{z} 79\left(\mathrm{M}^{+}\right)$

\section{Compound 41}

MS: $\mathrm{m} / \mathrm{z} 179\left(\mathrm{M}^{+}\right)$

\section{Results and Discussion}

A large number of methods to synthesize heterocycles containing benzothiophene ring have been reported in recent years [9,33-35], most of which involve the cyclization of benzenethiol derivatives. However, facile and versatile methods to access multi-substituted benzothiophenes are still limited. Furthermore, catalytic cyclization approaches using transition metals for the construction of the benzothiophene skeleton, which would provide a more efficient and practical route, are extremely rare in literature, presumably due to catalyst poisoning by sulfur; only few recent reports are known [36-40] and the described methodology is not applicable to the synthesis of all the substituted benzothiophenes.

\section{Synthesis of 4-substituted benzo[ $b]$ thiophenes}

Different ways are known for the preparation of 4-substituted benzothiophenes, but, generally, the retrosynthetic approach to the synthesis can be easily showed as in the next Scheme 1 .

Starting from commercial 4-oxo-4,5,6,7-tetrahydrobenzo[b] thiophene (1), we synthesized the key intermediate 4-hydroxybenzo[b] thiophene $[41,42]$ (3) in satisfactory chemical yields. Such compound can be transformed into 4-methoxybenzo[b]thiophene (4), 4-(tertbutyldimethylsilyloxy)benzo[b]thiophene (5), or into tert-butyl benzo[b]thiophen-4-yl carbamate (8) [19] in good yields as reported in Scheme 2.

As regards 4-hydroxybenzothiophene (3) we initially employed the classical synthesis in two steps (bromination followed by elimination of bromide and aromatization) shown in Scheme 2. During this reaction we observed the formation of the dibromide byproduct (2a in Figure 1) which, in the next step, results in the formation of $5-\mathrm{Br}$ 4-hydroxybenzothiophene (3a in Figure 1) hardly separable from the desired product (3) by chromatography with consequently low yield (45\%).<smiles>[R]c1cccc2sccc12</smiles><smiles>C=CC=C</smiles>

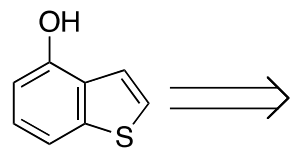<smiles>O=C1CCCc2sccc21</smiles>

$\mathrm{R}=\mathrm{OCH}_{3} ; \mathrm{NHBOC} ; \mathrm{NH}_{2}$

Scheme 1: Retrosynthetic scheme for 4-substituted benzo[b]thiophenes.
The importance of 4-hydroxybenzothiophene as key intermediate for the synthesis of the other 4-substituted benzothiophenes had required further investigation in order to improve the yield and to find mild conditions avoiding the use of $\mathrm{CCl}_{4}$ (a known carcinogen) and of molecular bromine because of its toxicity and difficulties associated with its manipulation (very corrosive liquid, highly toxic fumes).

So it was developed a new procedure (Scheme 3) which uses PHT (pyrrolidone hydrotribromide) as a brominating agent, according to a similar procedure reported in the literature [41].

The bromination was conducted in different solvents and experimental conditions in order to identify the optimal procedure. The reactions were followed by GC/MS in Table 1 was reported the percentage of conversion relative to the two brominated species. As shown in entry 6, reported conditions allow obtaining only the desired product in $86 \%$ of conversion. Applying the new methodology, it was possible to obtain an improvement of the overall yield of 4-hydroxybenzothiophene from $45 \%$ to $65 \%$ (Scheme 4 ).

Furthermore, we will emphasize how the new procedure provides very mild bromination conditions compared to the previous: the brominating agent (PHT) is a non-toxic non-corrosive solid and the reaction is conducted at room temperature and only for 2 hours under reflux of $\mathrm{CH}_{2} \mathrm{Cl}_{2}\left(40^{\circ} \mathrm{C}\right)$.
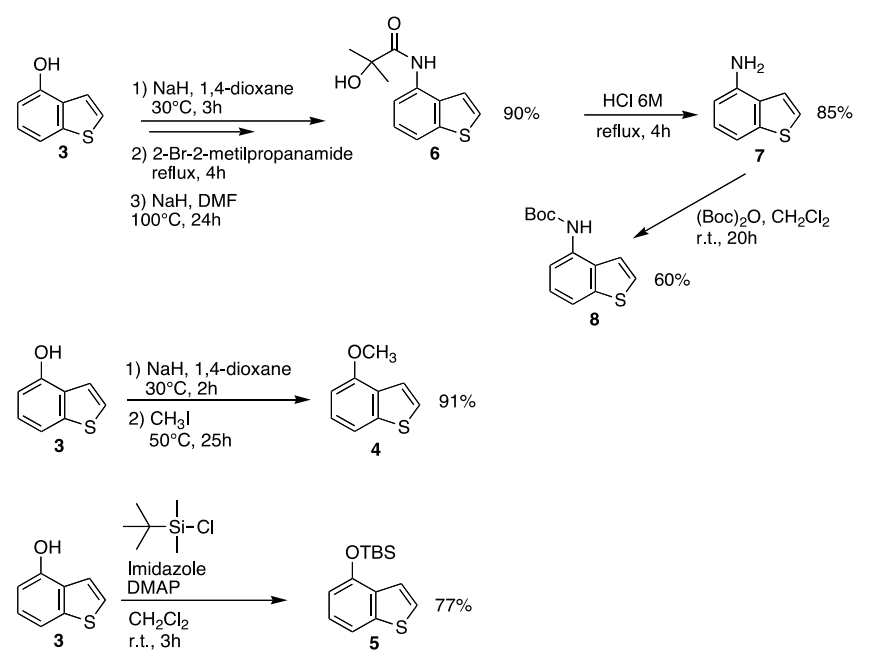

Scheme 2: Synthesis of 4-substituted benzo[b]thiophenes.<smiles>O=C1c2ccsc2CCC1(Br)Br</smiles>

$2 a$<smiles>Oc1c(Br)ccc2sccc12</smiles>

3a
Figure 1: Byproducts in the synthesis of 4-hydroxybenzothiophene.

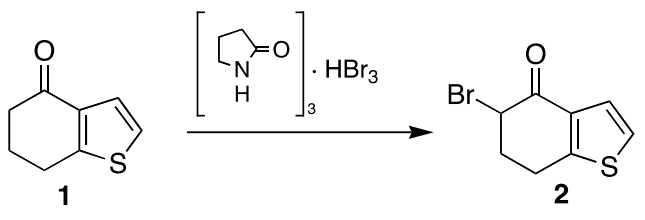

Scheme 3: New bromination procedure. 


\begin{tabular}{|c|c|c|c|c|c|}
\hline \hline Entry & Solvent & Conditions & Conversion \% & Product (2) & Byproduct (2a) \\
\hline $\mathbf{1}$ & 1,4-dioxane & r.t. $19 \mathrm{~h}$, reflux 1h30 & $89 \%$ & 82 & 18 \\
\hline $\mathbf{2}$ & 1,4 -dioxane & reflux 30 & $76 \%$ & 100 & 16 \\
\hline $\mathbf{3}$ & $\mathrm{CH}_{3} \mathrm{CN}$ & $80^{\circ} \mathrm{C}, 48 \mathrm{~h}$ & $83 \%$ & 100 & 0 \\
\hline $\mathbf{4}$ & $\mathrm{THF}$ & r.t. $17 \mathrm{~h}$, reflux $6 \mathrm{~h}$ & $73 \%$ & 96 & 0 \\
\hline $\mathbf{5}$ & $\mathrm{CH}_{2} \mathrm{Cl}_{2}$ & r.t. 22 h & $93 \%$ & 100 & 4 \\
\hline
\end{tabular}

Table 1: Optimization of bromination conditions.

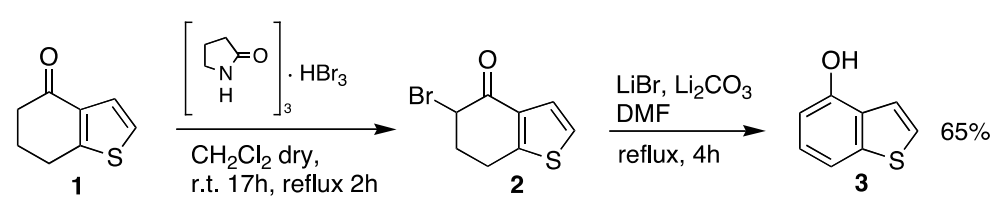

Scheme 4: Finally conditions for the synthesis of 4-hydroxybenzothiophene.

\section{Synthesis of 5 -substituted benzo[ $[b]$ thiophenes}

Preparation of 5 -substituted benzo[b]thiophenes is typically performed by cyclization of the corresponding (arylthio)-acetaldehyde diethylacetal or dimethylacetal in the presence of polyphosphoric acid [43-45] (see retrosynthetic Scheme 5), even if some catalytic methodologies have been recently reported in literature [36-40].

The main problem in the cyclization reaction is the low yields due to acid-catalyzed side reactions which lead complex mixture of byproducts [46-48]; this aspect is interesting from a kinetic point of view as recently reported [32].

Starting from commercial $p$-methoxybenzenethiol (9) we firstly synthesized 5- methoxybenzo[b]thiophene (13), from which we then obtained 5- hydroxybenzo[b]thiophene (12) and (Benzo $[b]$ thiophen5-yloxy)(tert-butyl)dimethylsilane (14) in good yields [32]. For the preparation of tert-butyl benzo[b]thiophen-5-yl-carbamate [49] (16) we started from commercial 5-aminobenzothiophene (15). Reaction conditions and results are reported in next Scheme 6.

\section{4- and 5-substituted benzo[b]thiophenes as scaffold for benzothienopyridines}

With these compounds in our hands we decided to use them as starting scaffolds for the synthesis of more complex heterocyclic structures. In particular, we focused on benzothienopyridines (Figure 2 a, b) with the aim to investigate new possible biological activities. In fact, it is well known that benzothienopyridines possess different pharmacological activities: their activity as antibacterial [50], antiallergic [51] and anxiolitic agents [52] were reported. Furthermore, pharmacological interest on benzothienopyridines is also due to their isosterism with indolopyridines [53,54]; recently also anti-cancer activity of such compounds has been reported [55].

Benzothienopyridines show some structural analogies with other small molecules recently reported in literature as new drugs for Alzheimer's disease [56-63] (Figures 3-5).

Some of such reported compounds are currently in preclinical studies as inhibitors of BACE1 [62,64]: this fact confirms the great interest in the introduction of heteroatoms and heterocyclic fragments in the design of new structures.

Hence, with the aim to study if benzothienopyridines could be have some activity in BACE1 inhibition, we designed the molecules in function of their multifunctionality: many different functional groups

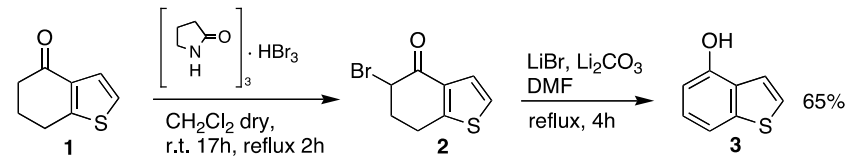

Scheme 5: Retrosynthetic scheme for 5-substituted benzo[b]thiophenes.
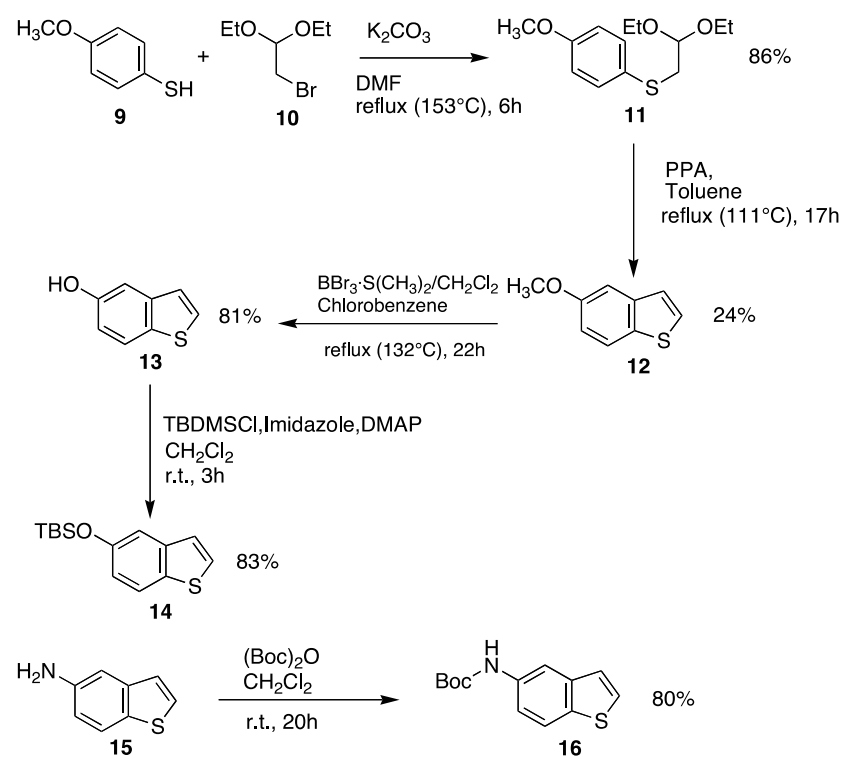

Scheme 6: Synthesis of 5-substituted benzo[b]thiophenes.

could be introduced both during the synthetic route or subsequently by modifying or using those already present (i.e., coupling with amino acids or similar).

The criteria for the choice of the synthetic strategy were the necessity of particular functional groups in opportune positions on the two aromatic rings.

The general retrosynthetic scheme applied is reported in next Scheme 7.

The depicted synthetic approach is based on three principal reactions: 
<smiles>[R]c1ccc2sc3nc(C)cc(P)c3c2c1</smiles>

a

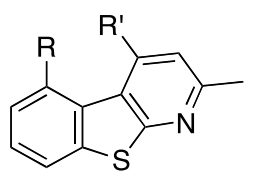

b
$\mathrm{R}=\mathrm{NHBoc} ; \mathrm{NH}_{2} ; \mathrm{OTBS} ; \mathrm{OH}$ $\mathrm{R}^{\prime}=\mathrm{COOCH}_{3} ; \mathrm{COOH}$

Figure 2: General structures of substituted benzothienopyridines.<smiles>COc1ccc(C(Cc2ccccc2)c2cccc(N)n2)cc1OC</smiles><smiles>CCOc1ccc(CC(c2ccccc2)c2cccc(N)n2)cc1</smiles>

Figure 3: Merk's inhibitors.<smiles>[R]c1ccc(Br)n1CC(=O)N=C(N)N</smiles>

Figure 4: Malamas's inhibitors.<smiles>COc1ccc(C(Cc2ccccc2)c2csc(N)n2)cc1</smiles><smiles>COc1ccc(C(Cc2cc([N+](=O)[O-])ccc2OC)c2csc(N)n2)cc1</smiles>

Figure 5: Stachel's inhibitors.

1) "azido-transfer" reaction that furnishes the azido precursors [65];

2) "Staudinger reaction" that transforms the azido group into an iminophosphorane one, a powerful tool for the construction of nitrogen-containing heterocycles [66-70];

3) tandem "aza-Wittig/electrocyclization" of iminophosphoranes with suitable $\alpha, \beta$-unsaturated carbonyl compounds [49].

To the obtained substituted benzothiophenes, the three steps synthetic scheme was applied and the results are reported in the schemes and tables (Tables 2-4).

\section{Azido transfer reaction}

Starting from the previous described 4-substituted-benzo[b] thiophenes, by using azidotransfer reaction, corresponding 2-azido heterocyclewere obtained in high yields due to the electron donating effect on the ring. As can be seen, the same groups in 5- position showed a smaller effect: chemical yields are lowered especially in the case of 2-azido compound with -OTBS (21) in 5 position, probably due to the less electronic enrichment on C-Li bond of thiophene ring.

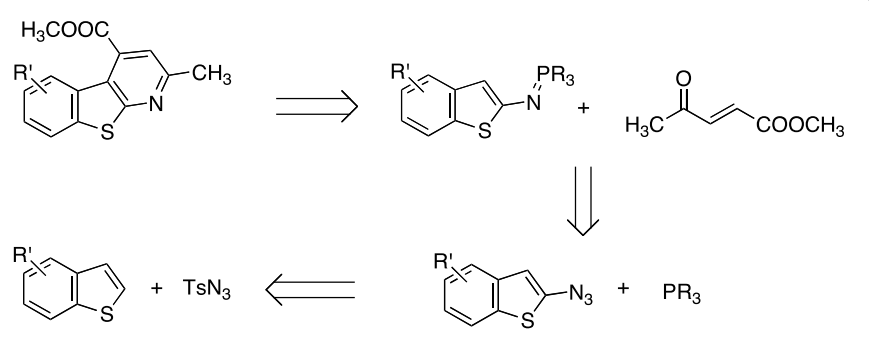

$\mathrm{R}^{\prime}=\mathrm{OCH}_{3}$; OTBS; OH $\mathrm{R}=\mathrm{Ph} ; \mathrm{CH}_{3}$

Scheme 7: Retrosynthetic scheme for benzothienopyridines preparation.

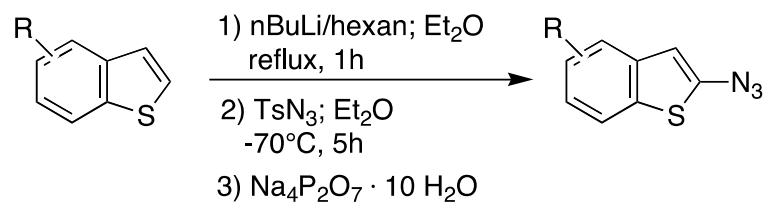

$\mathrm{R}=\mathrm{OCH}_{3}$; OTBS; NHAc; NHBoc

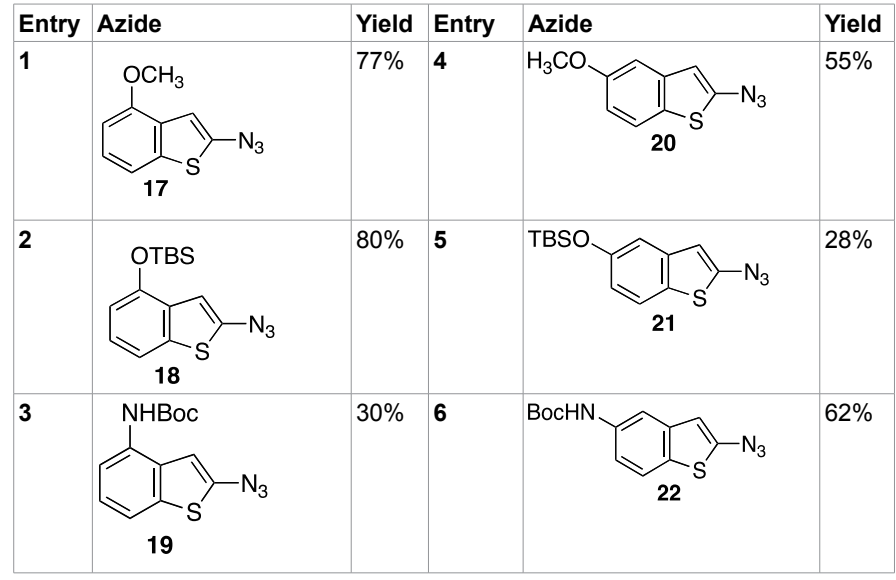

Table 2: Results of azido transfer reaction on 4- and 5-substituted benzothiophenes.

When we started from NHBoc-substituted benzothiophene the azido transfer reaction showed a drawback perhaps due to the presence of hydrogen on the aminic nitrogen: in fact, even by using excess of $\mathrm{n}$-BuLi, azide yield on 4-NHBoc-benzothiophene (19) was very low (we hyphotized that $\mathrm{NH}$ could react during lithiation phase despite the steric hindrance of tert-butoxycarbonyl group).

However, the same reaction on 5-NHBoc furnish azide (22) in better chemical yields, probably due both to electronic effects than to an improved shielding effect of the $\mathrm{NH}$.

\section{Staudinger reaction}

This reaction represents an interesting way to use a reactive function such as azido group in easy conditions by transforming in phosphorane, a very stable compound.

The best result in terms of yield has occurred in the case of iminophosphorane (23): Staudinger reaction starting from azide (17) with methyl(diphenyl)phosphine afforded the product (23) in $84 \%$ yield; in the case of the same reaction using triphenylphosphine, instead, there was a sharp drop in yield (24) [71,72].

The different reactivity of starting azide (17) is probably due both to electronic than to steric effects. The trend of reactivity is reversed starting from azide (20), which brings methoxyl group in 5-position, 

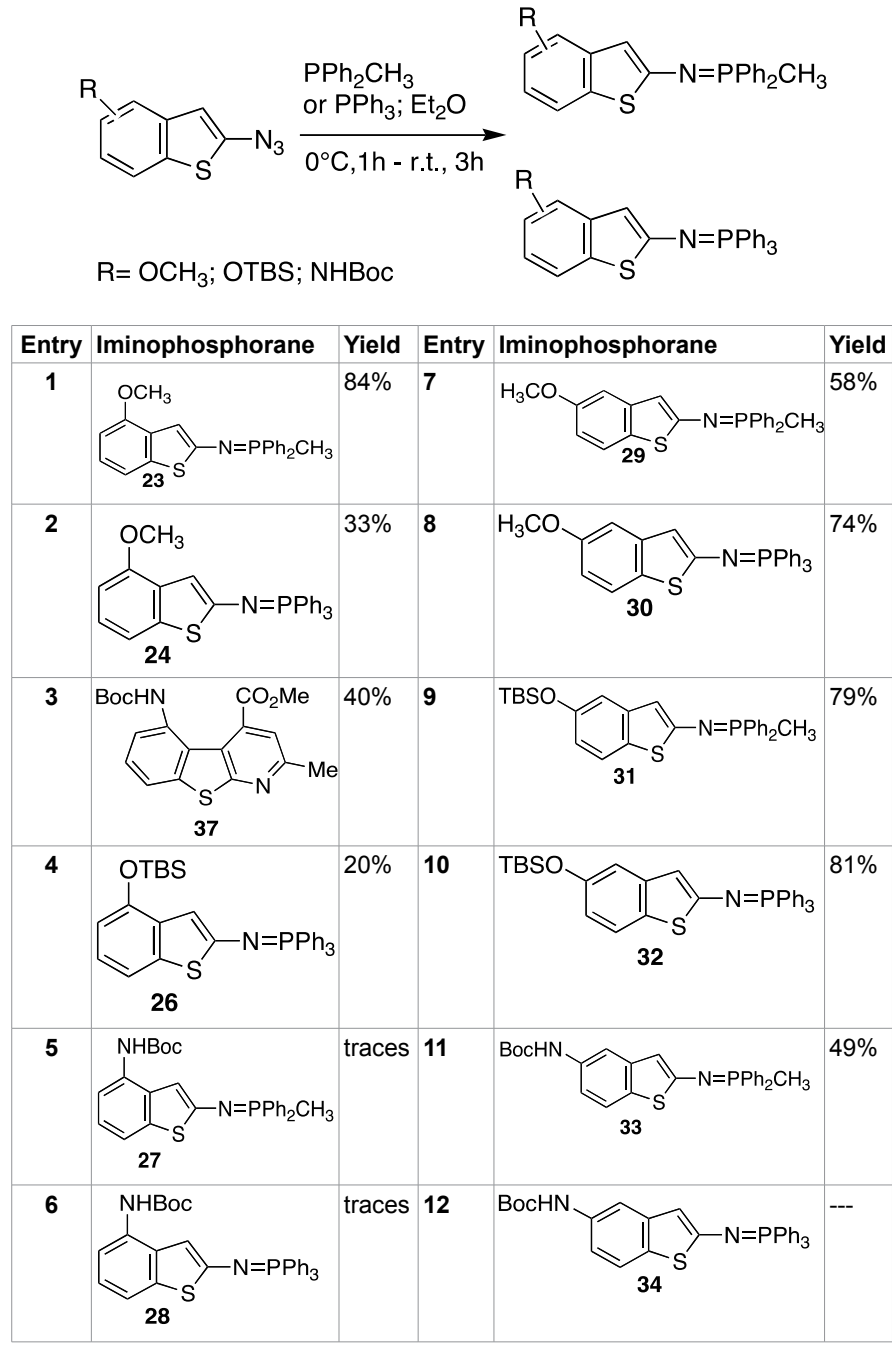

Table 3: Results of Staudinger reaction.

while the best result was observed for Staudinger reaction with triphenylphosphine (30). In the case of 4-OTBS derivatives the azide (18) showed less reactivity to Staudinger reaction, in particular with triphenylphosphine (iminophosphorane (26)), probably due to the steric hindrance either on the phosphorus than on the oxygen.

Unfortunately, iminophosphoranes resulting from 4-NHBoc derivatives were obtained only in traces, except for compound (33); no product was observed starting from 5-NHBoc-benzothiophenes(22) in the reaction with triphenylphosphine.

The trends observed can be explained on the basis of the mechanism of Staudinger reaction which initially involves the attack of the phosphorus on the azide to form a phosphazide intermediate as effectively reported in previous work [28]. If in the phosphazide the nucleophilicity of the nitrogen atom is not such as to favuor the intramolecular attack of the phosphorus, iminophosphorane formation may not occur.

In this view, the presence of electron releasing groups on the benzothiophene ring such as the methoxy and the OTBS favors this attack and consequently leads to higher yields in iminophosphorane; on the contrary, the presence of electron withdrawing groups, such as the Boc, disadvantage such attack. In fact, with the exception of iminophosphorane (33) obtained in $49 \%$ yield, in the other cases the

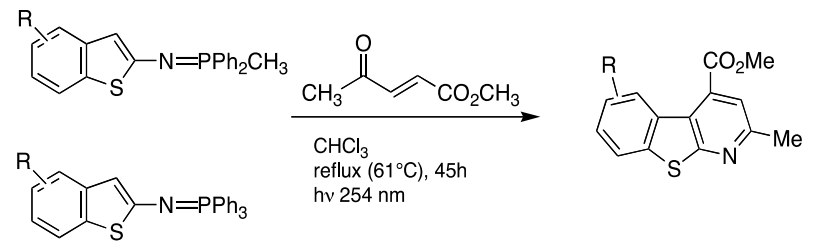

$\mathrm{R}=\mathrm{OCH}_{3}$; OTBS; NHBoC

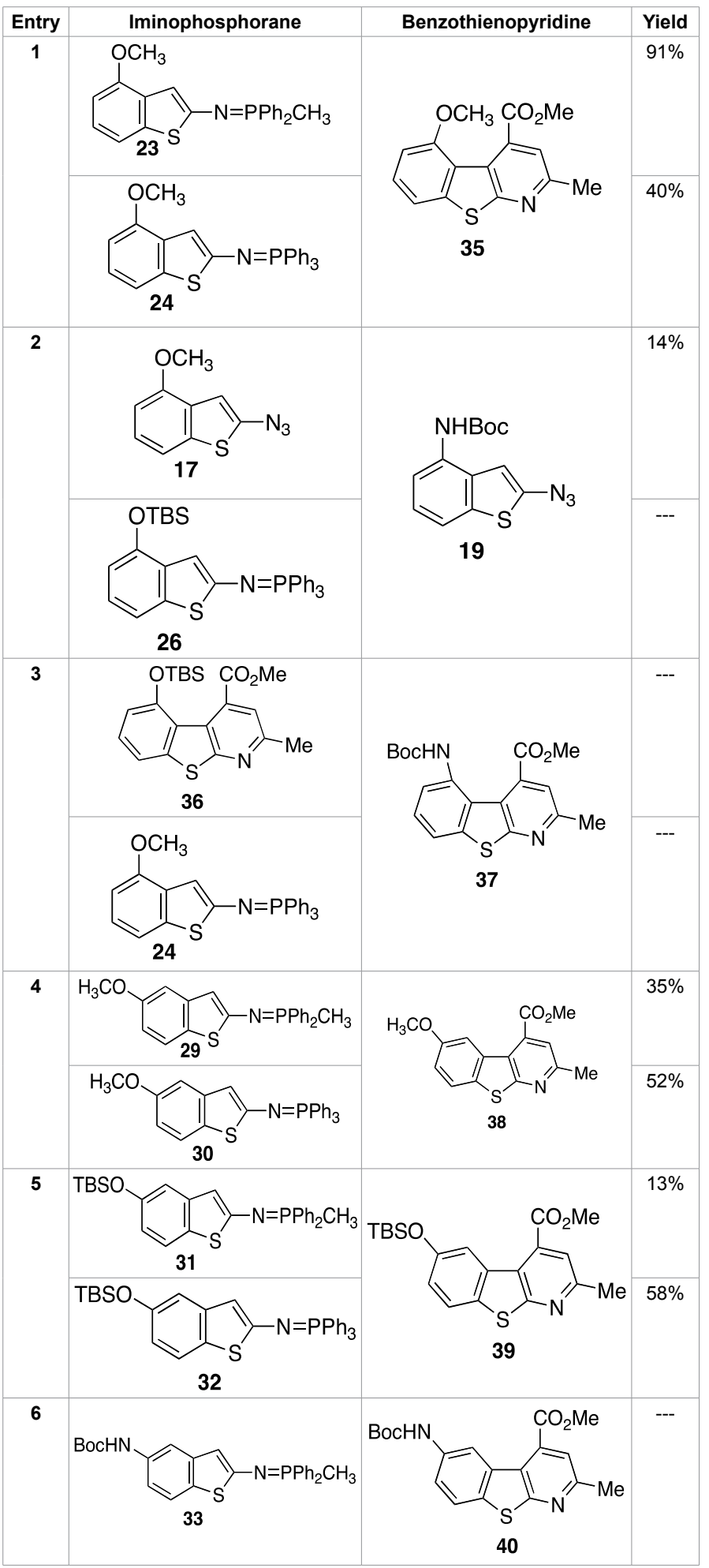

Table 4: Results of Aza-Wittig/electrocyclization. 
reaction did not take place (34) or led only to traces of the desired product $(\mathbf{2 7}, \mathbf{2 8})$.

\section{Aza-Wittig/electrocyclization}

The tandem aza Wittig/electrocyclization reaction represented the most important way to obtain pyridine and pyrimidine derivatives in good to excellent yields and in mild conditions. The reaction is well known in literature since 1970 and often used for the synthesis of different tricyclic compounds, such as benzothieno-, benzofuro- and indolopyridine.

The best result in terms of final yield (91\%) is represented by benzothienopyridine (35), facile obtained in the cyclization of iminophosphorane (23). Also in this case, the effect of the presence of methoxy group on the benzothiophene ring was important and we a reverse reactivity of 5- substituted iminophospohoranes compared to the corresponding 4- derivatives can be observed.

On the other hand, the presence of a much more hindered group such as OTBS in 4- position results in a significantly lowering in product yield (36) starting from iminophosporane (25) and no cyclization product was observed starting from iminophosporane (26). Opposite effect is observed for 5-OTBS derivatives: in this case the desired product (39) was obtained in 13\% yield starting from iminophosphorane (31) and in 58\% yield starting from iminophosphorane (32). As regards NHBoc derivatives, electronic effects, which contrast/counteract not only to cyclization reaction but also to imine formation, play a crucial role; no cyclization products were observed in these cases.

\section{Biological Essays}

Beta secretase (BACE1) is an aspartyl protease that shows a crucial role in developing of Alzheimer Disease: in fact it seems plays a wrong cut of APP in neurons generating A $\beta$-amiloyd peptide, which deposits out of neurons blocking the communication between this type of cells. The exact action 's mechanism of this enzyme is not yet well known but seems that its active site interacts with heterocyclic small molecules, such as some reported in previous Figures 3-5.

So we decided to test in vitro all the obtained benzothienopyridines for anti BACE 1 activity and some interesting value of $\mathrm{IC}_{50}$ (inhibitor concentration needed to reduce enzyme activity by $50 \%$ ) were obtained and reported in Table 5.

In particular, to evaluate inhibitory activity on BACE1 of such compounds, kinetic fluorimetric assays were carried out by FRET (Fluorescence Resonance Energy Transfer). Inhibitory activity was measured in accordance with methods described in literature [73] using $\beta$-Secretase human recombinant, expressed in HEK 293 cells (Gene ID 23621) supplied by Sigma Aldrich and the fluorogenic substrate ArgGlu(EDANS)-(Asn670, Leu671)-Amyloid B/A4 Protein Precursor770 (668-675)-Lys (DABCYL)-Arg supplied by Bachem (Bubendorf, CH) [74].

Compound 40 was obtained as byproduct in the Studinger reaction: even not belonging to the class of benzothienopyridines those smaller molecules were already tested on BACE1 to assess their activity. Compounds $\mathbf{4 2}$ and $\mathbf{4 3}$ were obtained after removal of TBS protecting group. Isomer $\mathbf{4 4}$ was obtained during the aza-Wittig electrocyclization step and isolated after purification. All compounds showed inhibitory activity values (IC50) in the range of micromolar scale. These promising results are comparable with the data of BACE1 known inhibitors [58$61,63]$ and actually are object of an Italian patent [74].

\section{Conclusions}

In this paper preliminary new heterocyclic compounds as inhibitors

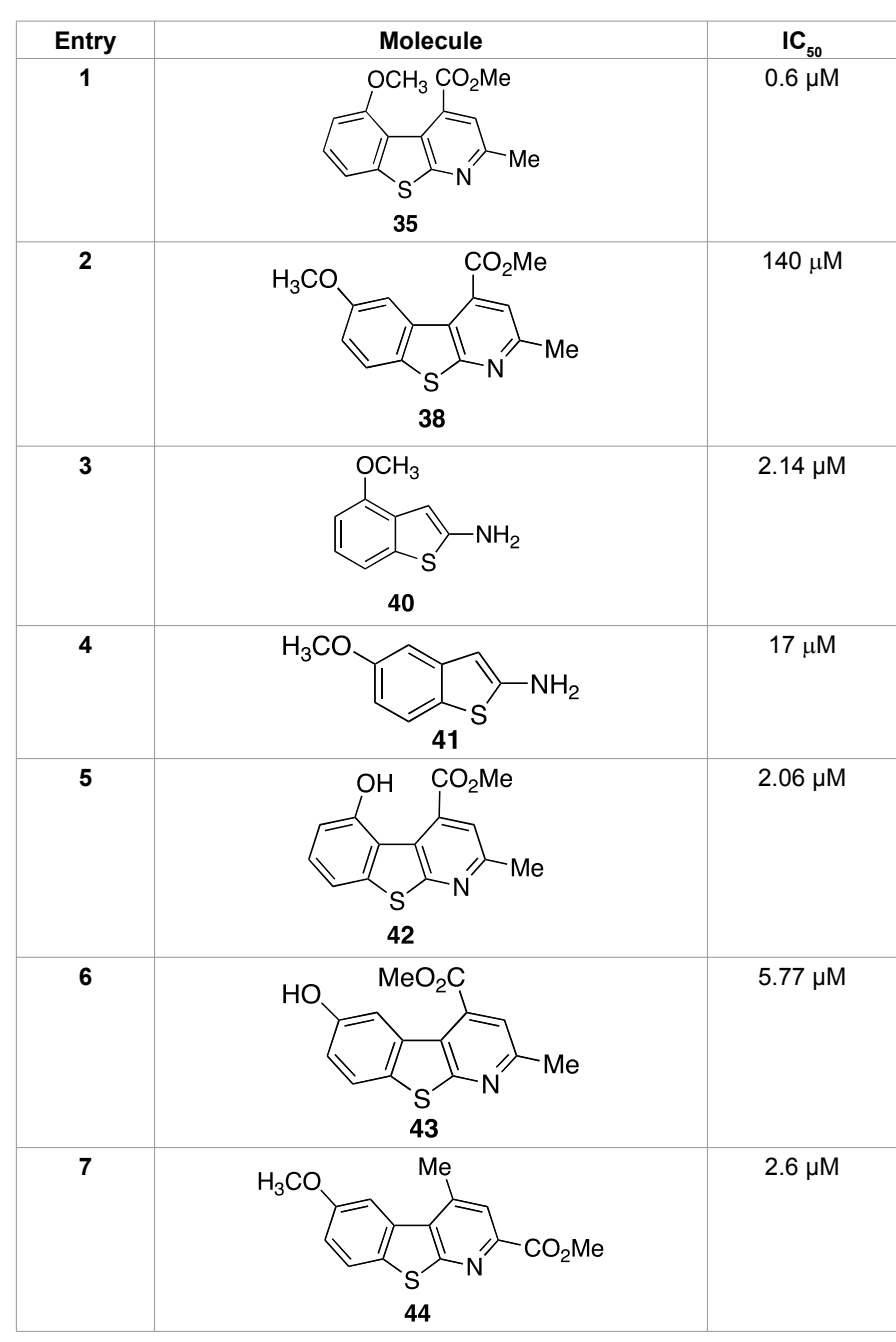

Table 5: Biological data.

of BACE 1 are described. Among the reported compounds 35 and 42 showed higher inhibitory performance probably due to a better interaction of these molecules in the active site of the enzyme. The work is in progress to enlarge the library and to enrich the study of the interaction between inhibitors and catalytic site. Such research effort is oriented to obtained new and improved chemicals in Alzheimer's disease treatment. Obtained preliminary results encourage research advance and further developments.

\section{References}

1. Quin LD, Tyrell JA (2010) Common ring system and the naming of heterocyclic compounds. In Fundamentals of Heterocyclic Chemistry. John Wiley and Sons, Hoboken, NJ, USA, pp: 6-8.

2. Quin LD, Tyrell JA (2010) The scope of the field of heterocyclic chemistry. In Fundamentals of Heterocyclic Chemistry. John Wiley and Sons, Hoboken, NJ, USA, pp: $1-5$.

3. Carey JS, Laffan D, Thomson C, Williams MT (2006) Analysis of the reactions used for the preparation of drug candidate molecules. Org Biomol Chem 4: 2337-2347.

4. Abraham DJ (2003) Burger's Medicinal Chemistry and Drug Discovery. 6th edn Wiley Interscience, New York. Chem Abstr 143: 109740.

5. Makriyannis A, Biegel D (2004) Drug Discovery Strategies and Methods. Marcel Dekker Inc., New York. Chem. Abstr 140: 229394.

6. Wang S, Beck R, Blench T, Burd A, Buxton S, et al. (2010) Studies of Benzothiophene Template as Potent Factor IXa (FIXa) Inhibitors in Thrombosis. Med Chem 53: 1465-1472. 
7. Iddon B, Scrowston RM (1970) Adv. Heterocycl. Chem. 11: 177

8. Scrowston RM (1981) Adv. Heterocycl. Chem. 29: 171.

9. Bui CT, Flynn BL (2006) Solid-phase synthesis of 2,3-disubstituted benzo[b] thiophenes and benzo[b]selenophenes. J Comb Chem 8: 163-167.

10. Pelkey ET (2003) Prog Heterocycl Chem 15: 116.

11. Bianchini C, Meli A (1997) Thiophene, Benzo[b]thiophene and Dibenzo[b,d] thiophene as Precursors to Highly Conjugated Organosulfur Compounds. Synlett 643-649.

12. Irie M, Uchida K (1998) Synthesis and Properties of Photochromic Diarylethenes with Heterocyclic Aryl Groups. Bulletin of the Chemical Society of Japan 71: 985-996.

13. Chiummiento L, Funicello M, Lupattelli P, Tramutola F, Berti F, et al. (2012) Synthesis and biological evaluation of novel small non-peptidic HIV-1 PIs: the benzothiophene ring as an effective moiety. Bioorg Med Chem Lett 22: 2948-2950.

14. Magarian RA, Overacre LB, Singh S, Meyer KL (1994) Curr Med Chem 1: 61.

15. Jones CD, Jevnikar MG, Pike AJ, Peters MK, Black LJ, et al. (1984) Antiestrogens. 2. Structure-activity studies in a series of 3-aroyl-2-arylbenzo[b] thiophene derivatives leading to [6-hydroxy-2-(4-hydroxyphenyl)benzo[b]thien3-yl] [4-[2-(1-piperidinyl)ethoxy]-phenyl]methanone hydrochloride (LY156758), a remarkably effective estrogen antagonist with only minimal intrinsic estrogenicity. J Med Chem 27: 1057-1066.

16. Bryant HU, Dere WH (1998) Selective estrogen receptor modulators: an alternative to hormone replacement therapy. Proc Soc Exp Biol Med 217: 45-52.

17. Flynn BL, Verdier-Pinard P, Hamel E (2001) A novel palladium-mediated coupling approach to 2,3-disubstituted benzo(b)thiophenes and its application to the synthesis of tubulin binding agents. Org Lett 3: 651-654.

18. Pinney KG, Bounds AD, Dingeman KM, Mocharla VP, Pettit GR, et al. (1999) A new anti-tubulin agent containing the benzo[b]thiophene ring system. Bioorg Med Chem Lett 9: 1081-1086.

19. Zhang SX, Bastow KF, Tachibana Y, Kuo SC, Hamel E, et al. (1999) Antitumor agents. 196. Substituted 2-thienyl-1,8-naphthyridin-4-ones: their synthesis, cytotoxicity, and inhibition of tubulin polymerization. J Med Chem 42: 4081-4087.

20. Norman BH, Dantzig AH, Kroin JS, Law KL, Tabas LB, et al. (1999) Reversal of resistance in multidrug resistance protein (MRP1)-overexpressing cells by LY329146. Bioorg Med Chem Lett 9: 3381-3386.

21. Boschelli DH, Kramer JB, Connor DT, Lesch ME, Schrier DJ, et al. (1994) 3-Alkoxybenzo[b]thiophene-2-carboxamides as inhibitors of neutrophilendothelial cell adhesion. J Med Chem 37: 717-718.

22. Cobb RR, Felts KA, McKenzie TC, Parry GC, Mackman N (1996) A benzothiophene-carboxamide is a potent inhibitor of IL-1 beta induced VCAM1 gene expression in human endothelial cells. FEBS Lett 382: 323-326.

23. Gualberto A, Marquez G, Carballo M, Youngblood GL, Hunt SW 3rd, et al. (1998) p53 transactivation of the HIV-1 long terminal repeat is blocked by PD 144795, a calcineurin-inhibitor with anti-HIV properties. J Biol Chem 273: 7088-7093.

24. Miyazaki H, Murayama T, Ono S, Narita H, Nomura $Y(1997)$ Effects of R(-)1-(benzo[b]thiophen-5-yl)-2-[2-N,N-diethylamino)ethoxy]ethan ol hydrochloride (T-588), a novel cognitive enhancer, on noradrenaline release in rat cerebral cortical slices. Biochem Pharmacol 53: 1263-1269.

25. Raga M, Palacin C, Castello JM, Ortiz JA, Cuberes MR (1986) New imidazole antifungal agents derived from benzo[b]thiophene. Euro. J. Med. Chem -Chim Ther 21: 329-332.

26. Bleavins MR, de la Iglesia FA, McCay JA, White KL Jr, Munson AE (1995) Immunotoxicologic studies with $\mathrm{Cl}-959$, a novel benzothiophene cell activation inhibitor. Toxicology 98: 111-123.

27. Wright CD, Stewart SF, Kuipers PJ, Hoffman MD, Devall LJ, et al. (1994) Selective regulation of human neutrophil functions by the cell activation inhibito Cl-959. J Leukoc Biol 55: 443-451.

28. Funicello M, Spagnolo $P$ (2005) Target in heterocyclic chemistry 8: 234-251.

29. Cole SL, Vassar R (2008) The role of amyloid precursor protein processing by BACE1, the beta-secretase, in Alzheimer disease pathophysiology. J Biol Chem 283: 29621-29625
30. Vassar R, Bennett BD, Babu-Khan S, Kahn S, Mendiaz EA, et al. (1999) Beta-secretase cleavage of Alzheimer's amyloid precursor protein by the transmembrane aspartic protease BACE. Science 286: 735-741.

31. Hong L, Koelsch G, Lin X, Wu S, Terzyan S, et al. (2000) Structure of the protease domain of memapsin 2 (beta-secretase) complexed with inhibitor. Science 290: 150-153.

32. Cerminara I, D'Alessio L, D'Auria M, Funicello M, Guarnaccio A (2016) 5-Substituted Benzothiophenes: Synthesis, Mechanism, and Kinetic Studies. Helvetica Chimica Acta 99: 384-392.

33. Kotsuki H, Ikishima H, Okuyama A (2008) Organocatalytic Asymmetric Synthesis Using Proline and Related Molecules. Heterocycles 75: 757-797.

34. Yoshida S, Yorimitsu H, Oshima K (2007) Synthesis of benzo[b]thiophenes by cyclization of arylketene dithioacetal monoxides under pummerer-like conditions. Org Lett 9: 5573-5576.

35. Jeong HJ, Yoon UY, Jang SH, Yoo Un-A, Kim SN, et al. (2007) A New Zn/TiCl4 LiAlH4 Mediated Approach to 2-Aryl- or 2-Alkyl-Substituted Benzothiophenes via Intramolecular Cyclization. Synlett 9: 1407-1410.

36. Nakamura I, Sato T, Yamamoto Y (2006) Gold-catalyzed intramolecular carbothiolation of alkynes: synthesis of 2,3-disubstituted benzothiophenes from (alpha-alkoxy alkyl) (ortho-alkynyl phenyl) sulfides. Angew Chem Int Ed Engl 45: 4473-4475.

37. Willis MC, Taylor D, Gillmore AT (2006) Palladium-catalysed intramolecular enolate O-arylation and thio-enolate S-arylation: synthesis of benzo[b]furans and benzo[b]thiophenes. Tetrahedron 62: 11513-11520.

38. Inamoto K, Arai Y, Hiroya K, Doi T (2008) Palladium-catalysed direct synthesis of benzo[b]thiophenes from thioenols. Chem Commun (Camb) : 5529-5531.

39. Cheung CW, Surry DS, Buchwald SL (2013) Mild and highly selective palladium-catalyzed monoarylation of ammonia enabled by the use of bulky biarylphosphine ligands and palladacycle precatalysts. Org Lett 15: 3734-3737.

40. Cheung CW, Buchwald SL (2013) Mild and general palladium-catalyzed synthesis of methyl aryl ethers enabled by the use of a palladacycle precatalyst. Org Lett 15: 3998-4001.

41. Bekaert A, Provot O, Rasolojaona O, Alami M, Brion J (2005) N-Methylpyrrolidin2-one hydrotribromide (MPHT) a mild reagent for selective bromination of carbonyl compounds: synthesis of substituted 2-bromo-1-naphtols. Tetrahedron Letters, 46: 4187-4191.

42. Mukereje S, Jash SS, De A (1993) J Chem Res, p: 192.

43. Cheralathan KK, Palanichamy M, Murugesan V (2003) Liquid-Phase Cyclization of (Phenylthio)acetaldehyde Diethylacetal to Benzo[b]thiophene over Zn2+ lonExchanged Zeolite BEA. Catalysis Letters 86: 173-177.

44. Pérez-Silanes $S$, Martìnez-Esparza J, Oficialdegui AM, Villanueva $H$, Orùs L, et al. (2001) J. Heterocycl. Chem. 38: 1025-1030.

45. Ple PA, Marnett LJ (1988) Synthesis of substituted benzo[b]thiophenes by acidcatalyzed cyclization of thiophenylacetals and ketones. J. Heterocycl. Chem. 25: 1271-1272.

46. Clark PD, Clarke K, Ewing DF, Scrowston RM (1980) Addition reactions of benzo[b]thiophen. Part 1. Self-addition and addition of simple aromatic hydrocarbons. J. Chem. Soc. Perkin Trans. 1 677-685.

47. Clark PD, Clarke K, Ewing DF, Scrowston RM, Kerrigan F (1981) J. Chem. Res., p: 307.

48. Clark PD, Rahman LKA, Scrowston RM (1982) Addition reactions of benzo[b] thiophen. Part 4. Reactions of some acetoxy- and hydroxy-benzo[b]thiophens with benzene or toluene. J. Chem. Soc. Perkin Trans. 1815-821.

49. Cerminara I, Chiummiento L, Funicello M, Guarnaccio A, Lupattelli P (2012) Heterocycles in peptidomimetics and pseudopeptides: design and synthesis. Pharmaceuticals (Basel) 5: 297-316.

50. Görlitzer K, Kramer C (2000) Potential antiallergics. 3. Synthesis and transformations of 1,4-dihydro-4-oxo-(1)benzothieno(3,2-b)pyridine-2carboxylic acid esters. Pharmazie 55: 645-650.

51. Fevrier B, Dupas G, Bourguignon J, Queguiner G (1993) Synthesis of new 4-quinolone-type compounds in the benzo[b]thiophene series. J. Heterocycl. Chem. 30: 1085-1088.

52. Benham CD, Blackburn TP, Johns A, Kotecha NR, Martin RT, et al. (1995) The synthesis of pyrazolo[4,3-c]- and imidazo[4,5-c]-Aryl[e]fused pyridines as 
Citation: Funicello M, Cerminara I, Chiummiento L (2016) Heterocycles for Alzheimer Disease: 4- and 5-Substituted Benzothiophenes as Starting Scaffold in the Construction of Potential New Inhibitors of BACE 1. Med chem (Los Angeles) 6: 377-384. doi:10.4172/2161-0444.1000373

structural analogues of 4 -aminonicotinoates. Bioorg. Med. Chem. Lett. 5: 2455-2460.

53. Roques BP, Prange T, Oberlin R (1977) ${ }^{1} \mathrm{H}$ NMR studies of solvent effects on chemical displacements and couplings vincinaux of benzothienopiridines. Org. Magn. Reson. 9: 185-187.

54. Benoit R, Dupas G, Bourguignon J, Queguiner G (1987) Facile synthesis of anellated NADH models precursors. Synthesis 12: 1124-1126.

55. Vennemann M, Baer T, Groegor G, Braunger J, Petra G, et al. (2007) Benzothienopyridines for Use as Inhibitors of Eg5 Kinesin. US 0232596 A1.

56. Stains Cl, Mondal K, Ghosh I (2007) Molecules that target beta-amyloid ChemMedChem 2: 1674-1692.

57. Ghosh AK, Gemma S, Tang J (2008) beta-Secretase as a therapeutic target for Alzheimer's disease. Neurotherapeutics 5: 399-408.

58. Barrow JC, McGaughey GB, Nantermet PG, Rajapakse HA, Selnick HG, et al. (2005) 1,3,5-substituted phenyl derivative compounds useful as beta-secretase inhibitors for the treatment of alzheimer's disease. WO2005103020.

59. Barrow JC, Mcgaughey GB, Nantermet PG, Rajapakse HA (2005) 2, 4, 6 -substituted pyridyl derivative compounds useful as beta-secretase inhibitors for the treatment of alzheimer's disease. WO2005103043.

60. Coburn CA (2005) Merck \& Co. PCT Int. Appl WO200597767.

61. Barrow JC, Coburn CA, Nantermet PG, Selnick HG, Stachel SJ, et al. (2005) Phenylamide and pyridylamide beta-secretase inhibitors for the treatment of alzheimer's disease. (Merck \& Co.) PCT Int. Appl. WO2005065195.

62. Malamas MS, Erdei J, Gunawan I, Barnes K, Johnson M, et al. (2009) Aminoimidazoles as potent and selective human beta-secretase (BACE1) inhibitors. J Med Chem 52: 6314-6323.

63. Stachel SJ, Coburn CA, Rush D, Jones KL, Zhu H, et al. (2009) Discovery of aminoheterocycles as a novel beta-secretase inhibitor class: $\mathrm{pH}$ dependence on binding activity part 1. Bioorg Med Chem Lett 19: 2977-2980.
64. Coburn CA, Stachel SJ, Li YM, Rush DM, Steele TG, et al. (2004) Identification of a small molecule nonpeptide active site beta-secretase inhibitor that displays a nontraditional binding mode for aspartyl proteases. J Med Chem 47: 61176119.

65. Spagnolo $P$, Zanirato $P$ (1978) A convenient synthesis of azidothiophenes and some of their reactions. J. Org. Chem. 43: 3539-3541.

66. Barluenga J, Palacios F (1991) Synthesis and reactivity of lambda 5 -phosphazenes. Uses as synthetic intermediates. Org. Prep. Proced. Int. 23 $1-65$.

67. Golologov YG, Kasukhin L (1992) Recent advances in the Staudinger reaction. Tetrahedron 48: 1353-1406.

68. Molina P, Vilaplana MJ (1994) Iminophosphoranes: Useful Building Blocks for the Preparation of Nitrogen-Containing Heterocycles. Synthesis, pp: 11971218.

69. Wamhoff H, Richardt G, Stolben S (1995) Iminophosphoranes: Versatile Tools in Heterocyclic Synthesis. Adv. Heterocyclic Chem. 64: 159-249.

70. Fresneda PM, Molina P (2004) Application of Iminophosphorane-Based Methodologies for the Synthesis of Natural Products. Synlett, pp: 1-17.

71. Bonini C, Chiummiento L, Funicello M, Spagnolo P (2000) N-(3-Benzo[b] thienyl)iminophosphoranes toward the Synthesis of Benzo[b]thieno[3,2-b] pyridines: Reactivity and Alternative Regioselectivity with $\alpha, \beta$-unsaturated Ketones and Aldehydes. Tetrahedron 56: 1517-1521.

72. Bonini C, D'Auria M, Funicello M, Romaniello G (2002) Novel N-(2-benzo[b] thienyl)iminophosphoranes and their use in the synthesis of benzo[b] thieno[2,3-b]pyridines. Tetrahedron 58: 3507-3512.

73. Tossi A, Bonin I, Antcheva N, Norbedo S, Benedetti F, et al. (2000) Aspartic protease inhibitors. An integrated approach for the design andsynthesis of diaminodiol-based peptidomimetics. Eur J Biochem 267: 1715-1722.

74. Berti F, Cerminara I, Funicello M (2015) Patent PTIT 13842015. 